\title{
Chemical Composition, Antioxidant and Antibacterial Activities of Lavender and Marjoram Essential Oils
}

\author{
F.A. Gharib, S.E.A. Badr ${ }^{*}$, B.A.S. Al-Ghazali ${ }^{* *}$ and M.K. \\ Zahran $^{* * \#}$ \\ Botany Department, Faculty of Science, Helwan University, \\ Ain-Helwan, Cairo, 11795, "Regional Center for Food and Feed \\ (RCFF), Agricultural Researches Center, Giza, 588 Orman and \\ ${ }^{* *}$ Chemistry Department, Faculty of Science, Helwan University, \\ Ain-Helwan, Cairo, 11795 Egypt.
}
I N THIS STUDY we assessed the chemical composition, antioxidant 1 and antibacterial activities of lavender (Lavandula angustifolia) and marjoram (Majorana hortensis) essential oils (EOs). Marjoram and lavender EOs showed promising antioxidant and free radical scavenging activities by 1,1-diphenyl-2-picryl-hydrasyl (DPPH) radical scavenging assay, $\beta$-carotene bleaching test and 2,2'-azinobis (3-ethylbenzothiazoline-6-sulfonic acid) (ABTS) assay. The three applied methods have shown that marjoram essential oil displays a strong antioxidant activity as well as good antibacterial activity.

GC/MS analyses indicated that $L$. angustifolia essential oil consisted of linalool as the most abundant component $(37.65 \%)$, followed by linalyl acetate $(15.29 \%), \alpha$-muurolene $(8.59 \%)$, alloaromadendrene $(6.03 \%)$, B-phellandrene $(4.39 \%)$ and other minor components. On the other hand, $M$. hortensis essential oil consisted of terpinen-4-ol (48.98\%), $\alpha$-terpinol (11.75\%), $\gamma$-terpinene $(9.64 \%)$, spathulenol $(3.51 \%)$, linalyl acetate $(2.58 \%)$ and sabinene hydrate $(2.30 \%)$ as the main constituents.

Lavender and marjoram herbs presented considerable content of carbohydrates, protein, amino acids, crude fiber, EOs and minerals $(\mathrm{Fe}, \mathrm{Zn}$ and $\mathrm{Cu})$, low values of fats, ash and absence of mycotoxins.

Keywords: Lavender, Marjoram, Essential oil, Antioxidant, ABTS assay and Antibacterial.

Phytochemicals are sources of natural antioxidants used for health promotion, food preservation, food flavoring and cosmetics since they are safer to consumption and more environmentally friendly than their synthetic counterparts ${ }^{(1-4)}$. The most widely used synthetic antioxidants in food, namely butylated hydroxytoluene (BHT), butylated hydroxyanisole (BHA), propyl galate (PG) and tertiary butyl hydroquinone (TBHQ) have been suspected of causing or promoting negative health effects ${ }^{(1)}$. Spices and herbs are known for their health protective effect mostly attributed to their polyphenolic components, mainly flavonoids, phenolic acids, also, ascorbic acid and carotenoids which possess, antioxidant activity against the

\#Corresponding author: E-mail address: magdyzahran@yahoo.com 
Reactive Oxygen Species $(\mathrm{ROS})^{(5,6)}$. ROS induce oxidative damage to biomolecules like lipids, nucleic acids, proteins and carbohydrates. This damage causes the onset of many diseases such as rheumatoid, cirrhosis, arteriosclerosis, diabetes and cancer ${ }^{(7)}$.

Antioxidants are recognized for their potential in promoting health and lowering the risk for cancer, hypertension and heart disease ${ }^{(8)}$. The antioxidant properties of many herbs and spices are reported to be effective in retarding the process of lipid peroxidation in oils and fatty acids and have gained interest of many research groups ${ }^{(9,10)}$. Among the herbs and spices extensively studied, the plants and EOs obtained from the Lamiaceae (Labiatae) family possess a significant antioxidant activity; for example, those of oregano ${ }^{(11,12)}$ and lavender ${ }^{(4,13)}$.

Also, numerous scientific reports have highlighted an important antimicrobial activity of essential oils ${ }^{(14,15)}$, including mycotoxin-producing fungi, has also been tested ${ }^{(16)}$. These biological activities depend on the chemical compositions ${ }^{(17)}$ which vary according to the geographical origin, environmental and agronomic conditions ${ }^{(18)}$. Therefore, the evaluation of the biological activity of an essential oil should be supplemented with the determination of its chemical composition $^{(19)}$.

Lavender (Lavandula angustifolia) and marjoram (Majorana hortensis) are among the most important members of the Lamiaceae family. The Lavenders are a genus of about 25-30 species of flowering plants native to the Mediterranean region south to tropical Africa and to the many regions of Asia. The genus includes annuals, herbaceous plants, and small shrubs grow wild in the rocky soil $^{(20)}$. Lavender has been used for centuries as an herbal remedy. It yields a highly effective essential oil with very sweet overtones and can be used in balms, salves, perfumes, cosmetics and topical applications. Internally, lavender essential oil is believed to be of benefit for a multitude of problems, including stress, headaches, colds, liver and gallbladder problems, loss of appetite, as mouthwash and all types of skin problems: wounds, psoriasis, insect bites, stings and as an insect repellent ${ }^{(21,22)}$. On the other hand, marjoram (Majorana hortensis L.), commonly known as 'sweet marjoram', is a perennial herb native to Cyprus and eastern Mediterranean countries ${ }^{(23)}$. Marjoram is used world wide as a spice and highly esteemed as condiment for seasoning food products. Essential oils (EOs) from aerial parts of the plants are used in the flavour, perfumery and pharmaceutical industries. Marjoram is well known for its medicinal and insecticidal values ${ }^{(24)}$. The plant is also reported to possess anticancer ${ }^{(25)}$, antioxidant $^{(12,26)}$ and antimicrobial activities ${ }^{(27,28)}$

The chemical composition of the EOs of Lamiaceae species is very variable. The primary components of Lavandula angustifolia oil are linalool and linalyl acetate. Other components include $\alpha$-pinene, limonene, 1,8-cineole, cis- and trans-ocimene, 3-octanone, camphor, caryophyllene, terpinen-4-ol, lavendulyl acetate and allo-aromadendrene ${ }^{(4,29-31)}$. In China, the most abundant component in Egypt. J. Chem. 56, No.1(2013) 
Lavender essential oil is 1,5-Dimethyl-1-vinyl-4-hexenyl butyrate (43.73\%), followed by 1,3,7-octatriene, 3,7-dimethyl- (25.10\%), eucalyptol (7.32\%) and camphor $(3.79 \%)^{(32)}$. On the other hand, the major components of marjoram from different countries were found to be terpinen-4-ol, gamma-terpinene, $\alpha$ terpineol, sabinene and trans-sabinene hydrate ${ }^{(26,33)}$.

Aflatoxins and ochratoxim (mycotoxins) are secondary metabolites produced by Aspergillus and Penicilliwn genera ${ }^{(34,35)}$. They are among the most potent mutagenic and carcinogenic compounds known to be produced in nature ${ }^{(36)}$. The most important mycotoxin; aflatoxins are hepatotoxic, hepatocarcinogenic and ochratoxin, which is nephrotoxic and nephrocarcinogenic ${ }^{(37,38)}$. Potential contamination of the plants with mycotoxins is acutely and chronically toxic to both humans and animals. Several studies confined the occurrence of toxigenic mycoflora and mycotoxins in medicinal and herbal plants ${ }^{(38,39)}$. El-Kady et al. ${ }^{(40)}$ reported the presence of aflatoxins $(8-35 \mu \mathrm{g} / \mathrm{kg})$ and sterigmatocystin $(10-23 \mu \mathrm{g}$ $\mathrm{g} / \mathrm{kg}$ ) in marjoram samples collected at Assuit Governorate, Egypt.

The aim of the present study was to examine the chemical composition, antioxidant (by using three different methods, namely, 2,2-diphenyl-1picrylhydrazyl (DPPH) radical scavenging method; the $\beta$-carotene linoleate model system and 2,2'-azinobis (3-ethylbenzothiazoline-6-sulfonic acid (ABTS) assay) and antibacterial activities of lavender and marjoram essential oils, also, to evaluate nutrient content as well as absence of mycotoxins (aflatoxins and ochratoxim) in both herbs for safer application in food preservation and in medicine.

\section{Plant materials}

\section{Materials and Methods}

Lavender (Lavandula angustifolia) and marjoram (Majorana hortensis) were purchased from the Graduates Farm (GF), El- Minya, Governorate of the Western Assiut - Cairo desert road, Egypt in April 2010 during the flowering season. The herbs are free production of chemicals and solar dried (solar tunnel dryer).

\section{Chemicals and reagents}

All bio-chemicals employed in this study were of highest purity and obtained from E. Merck (Darmstadt, Germany) except, DPPH, TBHQ, B-carotene, linoleic acid, aflatoxin and ochratoxin standards were purchased from Sigma Chemical Co. (Sigma-Aldrich Gmb H, Sternheim, Germany). All organic solvents were of AR grade.

\section{Proximate composition determination}

The proximate analysis is the time honored standard method of feed analysis. It involves simple chemical techniques used to distinguish nutrients from nonnutrients. Components of the proximate analysis (carbohydrate, fats, crude protein, moisture, crude fiber, nitrogen free extract and ash) were determined in lavender and marjoram samples according to the Association of Official Analytical Chemists (AOAC) methods ${ }^{(41,42)}$. Using weight difference, moisture 
and ash were obtained. The fiber content was estimated from the loss in weight of crucible and its content on ignition. Carbohydrate was determined when the sum of the percentage of moisture, ash, crude protein and fats were subtracted from 100. The nitrogen value, which is the precursor for protein of a substance, was determined by micro- Kjeldahl method, involving digestion, distillation and finally titration of the sample. The nitrogen value was converted to protein by multiplying with a factor of 6.25. The factor is derived from the generalization that most proteins contain $16 \%$ nitrogen.

Silica (acid insoluble ash) is not a component of the proximate analysis. Silica is determined by extracting an ash sample with hydrochloric acid to remove soluble minerals such as calcium, potassium and sodium salts. The material remaining consists mostly of silica.

Mineral contents, i.e. copper $(\mathrm{Cu})$, iron $(\mathrm{Fe})$ and zinc $(\mathrm{Zn})$ were determined according to the method of $\mathrm{AOAC}^{(43)}$ and Iva et al. ${ }^{(44)}$, by inductive coupled plasma (ICP) "optima 2000".

\section{Method for determining toxins \\ Extraction}

Extraction of toxins from lavender and marjoram samples and the cleanup procedures were performed according to the $\mathrm{AOAC}^{(45)}$. Ground lavender and marjoram samples $(50 \mathrm{~g})$ were mixed with $2.5 \mathrm{~g} \mathrm{NaCl}, 200 \mathrm{ml}$ of $80 \%$ (v/v) solution of methanol in water, $100 \mathrm{ml}$ of $n$-hexane and blended in a blender for 5 min. $100 \mathrm{ml}$ of the slurry solution was then centrifuged to remove the fat content extracted into the upper phase. After filtration, $25 \mathrm{ml}$ of the lower phase was shaken for $1 \mathrm{~min}$ in $25 \mathrm{ml}$ of chloroform in a separatory funnel. Finally, the chloroform phase was separated and evaporated to dryness at $50^{\circ} \mathrm{C}$. The extracted toxins in samples were then redissolved in $200 \mu \mathrm{L}$ of methanol. Finally, $5 \mu \mathrm{L}$ of this solution was introduced into the injection port of the HPLC. Stock solutions of each mycotoxins were prepared by dissolving solid commercial toxin in the appropriate solvent at concentration of $1 \mathrm{mg} / \mathrm{ml}$; aflatoxins in toluene/acetonitrile 99:1 and ochratoxins in toluene/acetic acid 99:1.

\section{Identification}

In order to verify the presence or absence of total alaflatoxins and ochratoxins in the lavender and marjoram samples, Immune affinity column and HPLC technique (Agillent 1200) series U.S.A were used_according to $\mathrm{AOAC}^{(46)}$. For aflatoxins determination column $\mathrm{C}_{18}$, Lichrospher $100 \mathrm{RP}-18,5 \mu \mathrm{m} \times 25 \mathrm{~cm}$ were used. The mobile phase consisted of water: methanol: acetonitrite (54:29:17, $\mathrm{v} / \mathrm{v} / \mathrm{v}$ ) at flow rate of $1 \mathrm{ml} / \mathrm{min}$. The excitation and emission wave lengths for all aflatoxins were 362 and $460 \mathrm{~nm}$ (Flourences detector), respectively according to $\mathrm{AOAC}^{(46)}$. Ochratoxin were determined using column Nova- Pak $\mathrm{C}_{18} 4 \mu \mathrm{m}, 3.9 \times$ $150 \mathrm{~mm}$. The mobile phase consisted of acetonitril: acetic acid : water (495:10: $495 \mathrm{v} / \mathrm{v} / \mathrm{v}$ ) at flow rate of $0.8 \mathrm{ml} / \mathrm{min}$. The excitation and emission wave lengths for ochratoxins were 333 and $477 \mathrm{~nm}$ (Flourences detector), respectively according to $\mathrm{AOAC}^{(46)}$.

Egypt. J. Chem. 56, No.1(2013) 


\section{Amino acids determination}

Amino acids determination for both lavender and marjoram samples was performed according to the method of $\mathrm{AOAC}^{(47)}$. Sample of $20-30 \mathrm{mg}$ weighted in conical flask and $5 \mathrm{ml}$ of performic acid was added. The flask was closed and inserted in ice water bath for $16 \mathrm{hr}$. Sodium metabisulfate $(1.0 \sim 1.5 \mathrm{~g})$ and $25 \mathrm{ml}$ of $\mathrm{HCl}(6 \mathrm{~N})$ were added to the oxidizing mixture. The flask was then subjected to high temperature $\left(110^{\circ} \mathrm{C}\right)$ for $24 \mathrm{hr}$ in oven. The flask was then applied to concentration in vacuo till dryness using rota evaporator. A suitable volume of sodium citrate puffer ( $\mathrm{pH} 2.20)$ was added to the dried film of hydrolyzed sample. The afforded soluble samples were then applied to the amino acids analyzer using Eppendorf LC 3000 (EZ Chrom, software used for data collection and processing). The results were calculated in percentage compared with the total crude protein.

\section{Method for determining essential oils composition \\ Isolation}

Quantitative determination of EOs from air-dried samples of lavender (Lavandula angustifolia) and marjoram (majorana hortensis) herbs was achieved by hydro-distillation for $3 \mathrm{hr}$ using a Clevenger-type apparatus. The obtained oil was dried over anhydrous sodium sulphate and after filtration, stored in a sealed vial at $-4^{\circ} \mathrm{C}$ until tested and analyzed.

\section{$G C-M S$ analysis}

Quantitative determination of the main oil fractions of the two dry herbs was analyzed by GC/MS at Cairo University Research Park, Giza, Cairo. The GC analysis was carried out using HP 6890 Series/ GC system equipped with HP5973/Mass selective detector operating by electron ionization (EI) at $70 \mathrm{eV}$, and TR-FAME capillary column ( $30 \mathrm{~m} \mathrm{X} 0.25 \mathrm{~mm}$ i.d, $0.25 \mu \mathrm{m}$ film thickness). The multi step temperature program was increased from $80^{\circ} \mathrm{C}$ (held for $2 \mathrm{~min}$ ) to $230^{\circ} \mathrm{C}$ (held for $2 \mathrm{~min}$ ) with rate of $3^{\circ} \mathrm{C} \mathrm{min}^{-1}$. The carrier gas was helium at a flow rate of $2 \mathrm{ml} \mathrm{min}^{-1}$ and the sample size was $1 \mu \mathrm{l}$ of diluted samples $(5 \mu \mathrm{l}$ oil $/ 2 \mathrm{ml}$ chloroform, v/v). Injector temperature was $250^{\circ} \mathrm{C}$ A spectral range of 35 $500 \mathrm{~m} / \mathrm{z}$ analysis was used. Identification of EO constituents was made by matching their recorded mass spectra with those stored in the Wiley/NBS mass spectral library of the GC-MS data system and other published mass spectra. Retention index was calculated for each compound using the retention times of a homologous series of $\mathrm{C}_{6}-\mathrm{C}_{26}$ n-alkanes ${ }^{(48)}$.

Antioxidant activity of lavender and marjoram essential oils

Diphenyl- 1-picrylhydrazyl (DPPH) radical scavenging method

The antioxidant activity of the lavender and marjoram EOs was assessed on the basis of the scavenging activity of the stable 2,2'-diphenyl-1-picrylhydrazyl free radical according to Matthus ${ }^{(49)}$. Various concentrations of EOs (i.e., 25, 50 and 100 $\mu \mathrm{g} / \mathrm{ml}$ ) were diluted five times with DPPH solution in methanol. The blank consisted of a $0.4 \mathrm{mM}$ methanolic solution of DPPH. After $30 \mathrm{~min}$ incubation at room temperature, the reduction in the number of free radicals was measured by reading the 
absorbance on a Jenway $6405 \mathrm{UV}-\mathrm{V}$ is spectrophotometer at $517 \mathrm{~nm}$. TBHQ was used as the reference standard. All determinations were performed in triplicate. The percentage inhibition of DPPH radical by each EO was calculated According to the following formula ${ }^{(50)}$ :

$\%$ Inhibition $=\left[\left(\mathrm{A}_{\mathrm{B}}-\mathrm{A}_{\mathrm{A}}\right) / \mathrm{A}_{\mathrm{B}}\right] \times 100$

where $A_{B}$ absorption of blank sample $\left(t=0\right.$ min) and $A_{A}=$ absorption of tested oil $(\mathrm{t}=30 \mathrm{~min})$.

$\mathrm{IC}_{50}$ values, which represented the concentration of EO or TBHQ that caused $50 \%$ scavenging, were determined from the plot of inhibition percentage against concentration.

\section{$\beta$-Carotene bleaching ( $B C B)$ method}

Antioxidant activity of the lavender and marjoram essential oils was determined according to slightly modified version of the $\beta$-carotene-linoleate model system as described by Wettasinghe and Shahidi ${ }^{(51)} . \beta$-carotene in $0.2 \mathrm{ml}$ of chloroform, $10 \mathrm{mg}$ of linoleic acid and $100 \mathrm{mg}$ of Tween-20 (polyoxyethylene sorbitan monopalmitate) were mixed. After evaporation to dryness, under vacuum at $40^{\circ} \mathrm{C}$, the resulting mixture was diluted with $10 \mathrm{ml}$ of water and mixed well for $1 \mathrm{~min}$ to form emulsion A. Four milliliter aliquots mixtures were pipette into different test tubes containing 25, 50 and $100 \mu \mathrm{g} / \mathrm{ml}$ and TBHQ (the same concentrations in ethanol. TBHQ was used for comparative purposes. A control containing $0.2 \mathrm{ml}$ of ethanol and $4 \mathrm{ml}$ of the above emulsion was prepared. The tubes were placed in a water bath at $50^{\circ} \mathrm{C}$ and the readings of all samples were taken immediately $(\mathrm{t}=0)$ and at 15 min intervals until the colour of $\beta$-carotene disappeared in the control tubes $(\mathrm{t}=60 \mathrm{~min})$ on a spectrophotometer at $470 \mathrm{~nm}$. A mixture prepared as mentioned above without $\beta$-carotene served as blank. All determinations were performed in triplicate. The antioxidant activity (AA) of extracts was evaluated in terms of bleaching of the $\beta$-carotene using the following formula :

$$
A A=100\left[1-\left(A_{o}-A_{t}\right) /\left(A^{o}{ }_{0}-A_{t}^{o}\right)\right]
$$

where : $\mathrm{A}_{\mathrm{o}}$ and $\mathrm{A}^{\mathrm{o}}$ ore the absorbance values measured at zero time of the incubation for test sample and control, respectively. $\mathrm{A}_{\mathrm{t}}$ and $\mathrm{A}_{\mathrm{t}}^{\mathrm{o}}$ are the absorbance of test sample and control, respectively, after incubation for $60 \mathrm{~min}$. The results were expressed in $\%$ basis in preventing bleaching of $\beta$-carotene.

\section{2,2'-Azinobis(3-ethylbenzothiazoline-6-sulfonic acid) (ABTS) assay}

Antioxidant activity was measured using an improved ABTS method as described by Cai et al. ${ }^{(52)}$. The ABTS radical cation $\left(\mathrm{ABTS}^{+}\right)$solution was prepared through the reaction of $7 \mathrm{mM}$ ABTS and $2.45 \mathrm{mM}$ potassium persulphate, after incubation at $23^{\circ} \mathrm{C}$ in the dark for $16 \mathrm{hr}$. The $\mathrm{ABTS}^{+}$solution was then diluted with $80 \%$ ethanol to obtain an absorbance of $0.700 \pm 0.005$ at $734 \mathrm{~nm}$. ABTS $^{+}$solution $(3.9 \mathrm{ml}$; absorbance of $0.700 \pm 0.005$ ) was added to 25,50 and $100 \mu \mathrm{g} / \mathrm{ml}$ of the lavender and marjoram EOs and mixed vigorously. The reaction mixture was allowed to stand at $23^{\circ} \mathrm{C}$ for $6 \mathrm{~min}$ and the absorbance was immediately recorded at $734 \mathrm{~nm}$. A standard curve was obtained by using Trolox standard solution at various concentrations Egypt. J. Chem. 56, No.1(2013) 
(ranging from 0 to $15 \mathrm{mM}$ ) in $80 \%$ ethanol. The absorbance of the reaction samples was compared to that of the Trolox standard and the results were expressed in terms of Trolox equivalents.

\section{Microbial strains and antibacterial susceptibility test}

Lavender and marjoram essential oils were individually tested against Bacillus cereus, Bacillus subtilis, Staphylococcus aureus, Escherichiea coli, Salmonella and Saccharomyces cerevisiae. These species were supplied by the Regional Center for Food and Feed Safety Lab., Agriculture Research Center, Giza, Egypt. The broth dilution method described in the Manual of Clinical Microbiology ${ }^{(3)}$ was used to assess the antibacterial activities of the lavender and marjoram EOs.

Minimal Inhibitory Concentration (MIC) test: Dilutions of each plant essential oil to be tested were prepared in $1.0 \mathrm{ml}$ volumes of sterile brain heart infusion broth to give a range of concentrations. After preparation of suspensions of test microorganisms (ca.106 organisms per $\mathrm{ml})$, one drop of suspension $(0.02$ $\mathrm{ml}$ ) was added to the extract broth dilutions. After $24 \mathrm{hr}$ incubation at $37^{\circ} \mathrm{C}$, the tubes were then examined for growth. MIC was defined as the lowest concentration of essential oil, showing no visible bacterial growth after incubation time. Methanol was included in as negative control.

\section{Statistical analysis}

Hydro-distillation of EOs and determinations of antioxidant activities were conducted in triplicate. Data were expressed as mean \pm standard deviation.

\section{Results and Discussion}

\section{Phytoconstituents and quality control}

As the vegetative parts of lavender with or without a small portion of the flowering tops of marjoram are used in the food and pharmaceutical industries, maintenance of quality of the produce is of utmost importance right from the harvesting stage onwards. All possible means should be taken to eliminate any chance of physical or microbial contamination.

Analysis of quality parameters of dry lavender and marjoram herbs includes fats $(2.77,1.49 \%)$, moisture $(6.40,7.70 \%)$, carbohydrates $(40.53,41.12 \%)$, proteins $(11.65,15.40 \%)$, fibers $(25.36,18.96 \%)$, ash $(9.22,11.45 \%)$, silica $(4.07,3.38 \%)$ and mineral elements such as iron $(1767.0,1608.0 \mathrm{ppm})$, zinc $(39.84,29.86 \mathrm{ppm})$, cupper $(25.88,14.94 \mathrm{ppm})$, respectively and absence of total aflatoxins and ochratoxin in both herbs (Table 1). Previous researchers on the typical chemical and physical specifications reported wide variations in the nutritional composition of Indian sweet marjoram ${ }^{(54)}$. El-Kady et al. ${ }^{(40)}$ highlighted the importance of quality control to prevent growth of fungi and bacteria in food products. They analyzed samples belonging to 24 kinds of marjoram spices collected from different places at Assuit Governorate (Egypt) for the natural occurrence of mycotoxins and reported for the first time the presence of aflatoxins $(8-35 \mu \mathrm{g} / \mathrm{kg}$ ) and sterigmatocystin $(10-23 \mu \mathrm{g} \mathrm{g} / \mathrm{kg})$ in 
different samples. However, they could not detect the presence of ochratoxin and zearalenone.

TABLE 1. Ingredients estimations of some chemical constituents of lavender $(L$. angutifolia) and marjoram (M. hortensis) dry herbs.

\begin{tabular}{|l|c|c|}
\hline $\begin{array}{l}\text { Ingredients } \\
(\%)\end{array}$ & $\begin{array}{c}\text { Lavender } \\
\text { (l. angutifolia })\end{array}$ & $\begin{array}{c}\text { Marjoram } \\
\text { (M. hortensis) }\end{array}$ \\
\hline Moisture & 6.40 & 7.70 \\
\hline Carbohydrates & 40.53 & 41.12 \\
\hline Protein & 11.65 & 15.40 \\
\hline Volatile oil & 0.59 & 0.80 \\
\hline Fibers & 25.36 & 18.96 \\
\hline Ash & 9.22 & 11.45 \\
\hline Fats & 2.77 & 1.49 \\
\hline Silica & 4.07 & 3.88 \\
\hline $\mathrm{Fe}^{++}(\mathrm{PPm})$ & 1767.0 & 1608.0 \\
\hline $\mathrm{Zn}^{++}(\mathrm{PPm})$ & 39.84 & 29.86 \\
\hline $\mathrm{Cu}^{++}(\mathrm{PPm})$ & 25.88 & 14.94 \\
\hline
\end{tabular}

TABLE 2. Amino acids constituents of lavender (L. angutifolia) and marjoram (M. hortensis) herbs.

\begin{tabular}{|l|c|c|}
\hline Amino Acids ( \%) & L.angustifolia & M. hortensis \\
\hline Aspargine & 0.76 & 0.83 \\
\hline Threonine* & 0.34 & 0.36 \\
\hline Serine & 0.35 & 0.41 \\
\hline Glutamine & 0.85 & 1.120 \\
\hline Proline & 0.38 & 0.43 \\
\hline Glycine & 0.48 & 0.46 \\
\hline Alanine & 0.46 & 0.68 \\
\hline Valine* & 0.44 & 0.52 \\
\hline Isoleucine* & 0.32 & 0.33 \\
\hline Leucine* & 0.65 & 0.64 \\
\hline Tyrosine & 0.00 & 0.34 \\
\hline phenylalanine* & 0.12 & 0.46 \\
\hline Histidin* & 0.12 & 0.16 \\
\hline Lysine* & 0.26 & 0.38 \\
\hline Arginine* & 0.24 & 0.80 \\
\hline Essential amino acids* & 2.490 & 3.650 \\
\hline Non Essential amino acids & 3.280 & 4.270 \\
\hline Essential amino acids*/ Non & 0.759 & 0.855 \\
\hline Essential amino acids & & \\
\hline & & \\
\hline & & \\
\hline
\end{tabular}

Egypt. J. Chem. 56, No.1(2013) 
On the other hand, amino acids composition of lavender and marjoram plants (Table 2) indicates that the ratios of essential amino acids (threonine, valine, leucine, iso-leucine, phenylalanine, histidine, lysine and arginine) are less than non essential amino acids (aspargine, serine, glutamine, proline, glycine, alanine and tyrosine) representing 0.759 and 0.855 in lavender and marjoram plants, respectively. Glutamine, aspargine, glycine and alanine (from non essential amino acids), leucine and valine (from the essential amino acids) are the major amino acids in lavender and marjoram plants. In addition, proline and serine (from non essential amino acids), arginine and phenylalanine (from the essential amino acids) are the major amino acids in marjoram plants.

From our study, lavender and marjoram originated and processed in Graduates Farm (GF), El- Minya, Governorate of the Western Assiut-Cairo desert road, Egypt, may have a high reputation in the world market due to their high quality of amino acids, proteins, minerals, low value of fats, ash and absence of mycotoxins.

\section{Essential oil}

Essential oil yield

The presented data in Table 1 reveal that distillation of aerial parts of lavender and marjoram yielded $0.59 \%$ and $0.80 \%$ pure light colourless oil, respectively on airdry weight basis. Previous research on the dried aerial parts of Lavandula angustifolia collected from the Botanical Garden, Faisalabad, Pakistan indicated similar oil content $(0.58 \mathrm{~g} / 100 \mathrm{~g})$ to the Egyptian counterpart ${ }^{(4)}$. On the other hand, according to Viuda-Martos, et al. ${ }^{(31)}$, the EO yield was $1.4 \%$ for lavender ( $L$. officinalis) collected from the city of Bilbeis in Sharkea region (NE, Cairo, Egypt) certified for organic biodynamic agriculture.

Moreover, Verma et al. ${ }^{(55)}$, reported lower EO yield $(0.35 \%$ on fresh weight basis) of the M. hortensis collected from the lower region of Kumaon Himalaya, India than our yield $(0.80 \%)$. Previous research on the hydro-distillation of aerial parts of M. hortensis cultivated in the Kumaon region of the western Himalaya, India registered variation in the essential oil content on fresh weight basis from $0.20 \%$ (early vegetative stage); $0.32 \%$ (late vegetative stage); $0.66 \%$ (flower initiation) to $0.70 \%$ at flowering stage (33). Our results may have differed due to different experimental conditions and harvest crop stage, which interfere with EO content and composition. Marotti et al. ${ }^{(56)}$ reported that EO yield and composition depend on pedoclimatic conditions and on the ontogenic stage of the plant.

\section{Essential oil constituents}

Table 3 shows the chemical constituents and their relative percentage of the total chromatogram area of lavender and marjoram EOs. GC/MS analyses of lavender EO identified 22 constituents; representing $97.53 \%$ of the total oil, linalool $(37.65 \%)$ was found as the main component. linalyl acetate $(15.29 \%)$ was the second major component detected in lavender oil. $\alpha$-Muurolene $(8.59 \%)$, allo-aromadendrene (6.03\%) and B-phellandrene (4.39\%) other components identified in lavender oil. The profile obtained in this study was similar to that reported by Viuda-Martos, et $a l^{(31)}$, for lavender cultivated in Egypt they reported a higher value for linalool (39.83\%), 
linalyl acetate $(32.11 \%)$, camphor $(11.29 \%)$ and $B$-phellandrene $(7.63 \%)$. Hassiotis et $a l .{ }^{(30)}$, reported a similar oil component with our findings but at different concentrations in native plants of lavenda a new variety of Lavandula angustifolia cultivated in Greece and in Etherio were the main components linalool (20.1 and $26.9 \%$, respectively) and linalyl acetate (13.3 and $22.8 \%$, respectively). However, there was a great variability in chemical composition of lavender EO obtained in this study than lavender grown in China, 1,5-dimethyl-1-vinyl-4hexenylbutyrate $(43.73 \%)$ was the main constituent followed by 1,3,7-octatriene, 3,7dimethyl- (25.10\%), eucalyptol $(7.32 \%)$ and camphor $(3.79 \%)^{(32)}$.

TABLE 3. Composition of essential oil of lavender (Lavandula angustifolia) and marjoram (Majorana hortensis) herbs.

\begin{tabular}{|c|c|c|c|}
\hline Oil components (\%) & RI & L. angustifolia & M. hortensis \\
\hline$\alpha$-pinene & 939 & - & 1.35 \\
\hline$\beta$-pinene & 981 & 2.52 & - \\
\hline$\beta$-phellandrene & 1053 & 4.39 & - \\
\hline Sabinene hydrate & 1073 & - & 2.30 \\
\hline$\gamma$-terpinene & 1074 & - & 9.64 \\
\hline Linalool & 1100 & 37.65 & - \\
\hline Camphor & 1139 & 1.99 & - \\
\hline Borneol & 1162 & 1.98 & - \\
\hline Terpinen-4-ol & 1179 & - & 48.98 \\
\hline cis-p-menth-2-en-1-ol & 1185 & - & 1.97 \\
\hline Piperitol & 1194 & - & 0.97 \\
\hline$\alpha$-terpineol & 1195 & - & 11.75 \\
\hline Linalyl acetate & 1261 & 15.29 & 2.58 \\
\hline Lavandulyl acetate & 1283 & 2.39 & - \\
\hline Isoborneol acetate & 1306 & 0.50 & - \\
\hline D-verbenone & 1308 & 0.62 & - \\
\hline$\beta$-elemene & 1393 & 1.15 & - \\
\hline$\gamma$-elemene & 1425 & - & 1.76 \\
\hline$\beta$-farnesene & 1445 & 4.35 & \\
\hline$\alpha$-guaiene & 1453 & 1.27 & - \\
\hline$\beta$-caryophyllene & 1467 & 3.60 & 0.81 \\
\hline$\gamma$-muurolene & 1475 & 0.58 & - \\
\hline$\beta$-guaiene & 1483 & 0.90 & - \\
\hline Allo aromadendrene & 1496 & 6.03 & - \\
\hline$\alpha$-muurolene & 1532 & 8.59 & - \\
\hline Nerolidol & 1539 & 0.43 & - \\
\hline Caryophyllene oxide & 1573 & 0.96 & 0.88 \\
\hline Spathulenol & 1619 & 0.80 & 3.51 \\
\hline A-bisabolol & 1662 & 0.56 & \\
\hline$\alpha$-santalol & 1672 & 0.98 & - \\
\hline Not identified compounds & & 2.47 & 13.50 \\
\hline
\end{tabular}

Egypt. J. Chem. 56, No.1(2013) 
In $M$. hortensis, 12 components were identified representing $86.50 \%$ of the total oil with terpinen-4-ol (48.98\%), $\alpha$-terpinol (11.75\%), $\gamma$-terpinene $(9.64 \%)$, spathulenol $(3.51 \%)$, linalyl acetate $(2.58 \%)$ and sabinene hydrate $(2.30 \%)$ as the main constituents followed by p-menth-1-en-2-ol (1.97\%), $\gamma$-elemene $(1.76 \%), \alpha$-pinene $(1.35 \%)$, piperitol $(0.97 \%)$, caryophyllene oxide $(0.88 \%)$ and $\beta$-caryophyllene $(0.81 \%)$. Similarly, the essential oil of $M$. hortensis cultivated in India was mainly composed of monoterpenes and to a small extent sesquiterpenes ${ }^{(55)}$. M. hortensis oil from different countries possessed terpinen-4ol as a major constituent representing $38.40 \%$ ( Reunion Island), 30.55\% ( mid hills of north India), 24.25\% (South India), 22.02\% (subtropical India), 20.39\% (Egypt) and $19.7 \%$ (Germany) $)^{(26,55,57-60)}$. However, linalyl acetate $(26.1 \%)$ followed by sabinene $(12.0 \%)$ were the principle components of marjoram oil of Iran origin ${ }^{(61)}$.

As mentioned above there was a great variability in the chemical composition of essential oils obtained from Egyptian lavender and marjoram herbs across provinces and countries. Such variability depends on several factors including local climatic and environmental conditions, season, geographical location, geology, genetic/chemotypic, nutritional status of the plants, part of the plant used and isolation process ${ }^{(32)}$

\section{Antioxidant activity}

Owing to the complex reactive facets of phytochemicals, the antioxidant activities of plant extracts cannot be evaluated by only a single method to establish authenticity ${ }^{(62)}$. There are many different methods for determining antioxidant function each of which depends on a particular generator of free radicals, acting by different mechanisms ${ }^{(63)}$. The DPPH method is sensitive, requires small sample amounts, faster than $B$-Carotene-linoleic acid (BCB) assay and allows testing of both lipophilic and hydrophilic substances ${ }^{(64)}$. On the other hand, the BCB method is helpful especially for investigations of lipophilic antioxidants and it is appropriate for the investigation of the antioxidant activity of essential oils ${ }^{(65)}$. 2,2'-azinobis (3-ethylbenzothiazoline-6-sulfonic acid) (ABTS) assay is applicable to both lipophilic and hydrophilic antioxidants, permits the measurement of antioxidant activity of mixtures of substances and hence helps to distinguish between additive and synergistic effects ${ }^{(66)}$. For this reason the antioxidant activity of lavender and marjoram essential oils was determined by these three complementary spectrophotometric methods.

\section{DPPH Radical scavenging method}

Many radical species of different reactivity are formed during a lipid oxidation. Relatively stable organic radical DPPH has been widely used in the determination of the antioxidant activity of single compounds as well as the different plant extracts ${ }^{(67)}$. The DPPH assay measures the ability of the extract to donate hydrogen to the DPPH radical ${ }^{(68)}$, resulting in bleaching of the DPPH solution. The greater the bleaching action, the higher the antioxidant activity, which is reflected in a lower $\mathrm{IC}_{50}{ }^{(69)}$. Substrate polarity does not affect DPPH scavenging activity ${ }^{(65)}$. 
DPPH method was used to evaluate the antioxidant properties of the lavender and marjoram EOs in comparison with synthetic antioxidants TBHQ.

Table 4 shows a highly significant decrease in the DPPH radical concentration due to the scavenging activity of each oil concentration and standards. Marjoram EO showed a high radical scavenging activity (83.2\%), followed by lavender EO (78.1\%) and both EOs were less than positive controls TBHQ $(89.7 \%)$ at $100 \mu \mathrm{g} / \mathrm{ml}$. The values of $\mathrm{IC}_{50}$ was in the order TBHQ < Marjoram < Lavender. Similarly, using DPPH radical scavenging method, the antioxidant activities of Lavender ( $L$. angustifolia) EO from aerial parts were significantly lower than patchouli (Pogostemon cablin); lemon balm (Melissa officinalis); salvia (Salvia officinalis) and reference standard BHT $\left(\mathrm{IC}_{50}=289.0\right.$, $225.7,69.9,62.3$ and $9.9 \mu \mathrm{g} / \mathrm{ml}$, respectively ${ }^{(4)}$ and lower than our lavender oil $\left(\mathrm{IC}_{50}=60.53\right)$. On the contrary, the highest DPPH was obtained by lavender EO; highest ABTS radical scavenging assay was obtained in peppermint ( $M$. piperita) EO; lavender oil was most effective for inhibiting linoleic acid peroxidation after 10 days $^{(13)}$. Kulisic et al. ${ }^{(11)}$, found that $\mathrm{IC}_{50}=0.50$ and $1.8 \times 10^{-2}(\mathrm{~g} / \mathrm{l})$ for EO (air-dried flower tops and stalks) of Oregano ( $O$. vulgare $\mathrm{L}$ ) and BHT, respectively and by the same method, ethanolic extract of the aerial parts Oregano $\left(O\right.$. heracleoticum) gives $\mathrm{IC}_{50}=12.8 \mu \mathrm{g} / \mathrm{ml}^{(70)}$, which means higher antioxidant activities than our marjoram oil. Our results indicated different values for $\mathrm{IC}_{50}\left(\mu \mathrm{gmL}^{-1}\right)$ for TBHQ by using DPPH and B-Carotene, assays being 36.65 and 16.25, respectively. Similarly, $\mathrm{IC}_{50}\left(\mu \mathrm{gmL}^{-1}\right)$ for BHT, using DPPH, ABTS, $\beta$-carotene assays recorded $87.98,77.85$ and 36.85 , respectively ${ }^{(71)}$.

TABLE 4 . DPPH scavenging activity of different concentrations $(25,50,100 \mu \mathrm{G} / \mathrm{MI})$ of lavender (Lavandula angustifolia) and marjoram (Majorana hortensis) EOs and the synthetic antioxidants (TBHQ).

\begin{tabular}{|l|l|l|l|l|}
\hline Lamiaceae species & \multicolumn{4}{|c|}{ DPPH \% inhibition } \\
\hline & $\mathbf{2 5} \boldsymbol{\mu g} / \mathbf{m l}$ & $\mathbf{5 0} \boldsymbol{\mu g} / \mathbf{m l}$ & $\mathbf{1 0 0} \boldsymbol{\mu g} / \mathbf{m l}$ & $\mathbf{I C}_{\mathbf{5 0}}(\boldsymbol{\mu g} / \mathbf{m l}) *$ \\
\hline Lavender (L. angustifolia) & $16.5 \pm 1.3$ & $50.3 \pm 1.4$ & $78.1 \pm 2.1$ & $60.53 \pm 0.21$ \\
\hline Marjoram (M. hortensis) & $24.7 \pm 1.8$ & $57.7 \pm 1.9$ & $83.2 \pm 1.4$ & $51.90 \pm 0.22$ \\
\hline Synthetic antioxidants (TBHQ) & $67.5 \pm 1.5$ & $76.3 \pm 2.4$ & $89.7 \pm 2.7$ & $36.65 \pm 1.07$ \\
\hline
\end{tabular}

$\mathrm{IC}_{50}$ signifies concentration $(\mu \mathrm{g} / \mathrm{ml})$ for a $50 \%$ inhibition.

$\beta$-Carotene-linoleic acid assay

$\beta$-carotene bleaching test is based on the loss of the yellow colour of $\beta$ carotene due to its reaction with radicals which are formed due to linoleic acid oxidation in an emulsion. The rate of $\beta$-carotene bleaching can be slowed down in the presence of antioxidants. This fact is used in the antioxidant activity evaluation of the lavender and marjoram EOs in comparison with well known, synthetic TBHQ (Table 5). 
TABLE 5. Antioxidant activity of lavender (Lavandula angustifolia) and marjoram (Majorana hortensis) EOs using the corresponding concentrations (25, 50, $100 \mu \mathrm{G} / \mathrm{MI})$ measured by $B$ - carotene-linoleic acid method.

\begin{tabular}{|l|c|c|c|c|}
\hline \multicolumn{1}{|c|}{ Lamiaceae species } & \multicolumn{4}{c|}{$\beta$ - carotene-linoleic acid method } \\
\hline & $\mathbf{2 5} \boldsymbol{\mu g} / \mathbf{m l}$ & $\mathbf{5 0} \boldsymbol{\mu} \mathbf{g} / \mathbf{m l}$ & $\mathbf{1 0 0} \boldsymbol{\mu g} / \mathbf{m l}$ & $\mathbf{I C}_{\mathbf{5 0}}(\boldsymbol{\mu g} / \mathbf{m l})$ \\
\hline Lavender (L. angustifolia) & $39.7 \pm 1.4$ & $55.3 \pm 2.3$ & $75.4 \pm 2.7$ & $43.92 \pm 0.36$ \\
\hline Marjoram (M. hortensis) & $43.5 \pm 2.1$ & $61.1 \pm 1.9$ & $81.2 \pm 2.4$ & $34.44 \pm 0.54$ \\
\hline Synthetic antioxidants (TBHQ) & $76.9 \pm 3.1$ & $84.2 \pm 2.4$ & $97.2 \pm 1.7$ & $16.25 \pm 0.20$ \\
\hline
\end{tabular}

The inhibition of TBHQ and EOs was concentration dependant. The antioxidant power decreased in the order TBHQ > Marjoram EO > Laveder EO. These data are consistent with the results obtained using DPPH assay. According to Viuda-Martos et al. ${ }^{(31)}$, antioxidant activity of lavender (Lavandula officinalis) $)$ EO and BHT measured by DPPH $\left(\mathrm{IC}_{50}=48.7,0.53 \mathrm{~g} / \mathrm{L}\right)$ and inhibition of lipid peroxidation of buffered egg yolk (TBARS) assays $\left(\mathrm{EC}_{50}=\right.$ $34.92,0.001 \mathrm{~g} / \mathrm{L}$ ), where $\mathrm{EC}_{50}$ signifies concentration for a $50 \%$ inhibition. Other investigators previously reported that ascorbic acid, a well known polar antioxidant, showed a high antioxidant capacity by DPPH assay, but it was ineffective when tested by B-carotene bleaching test. Indeed, the polar molecules remain in aqueous phase and are consequently less efficient in protecting linoleic $\operatorname{acid}^{(19,72)}$. The DPPH assay allows the test of both lipophilic and hydrophilic substances while $\beta$-carotene bleaching test is dependent on substrate polarity. The high activity revealed by the $\beta$-carotene test indicates a good ability to function at the lipid water interface. Our results revealed that lavender and marjoram EOs possesses a good capacity to scavenge free radicals and to prevent lipid peroxidation.

\section{2,2'-Azinobis (3-ethylbenzothiazoline-6-sulfonic acid) (ABTS) assay}

The method is based on the progressive consumption of antioxidant activity by the 2,2'-azino-bis(3-ethylbenz-thiazoline-6-sulfonic acid) (ABTS) radical cation $\operatorname{ABTS}(+)$ as it is generated in the reaction cuvette and can be automated spectrophotometricly at $734 \mathrm{~nm}$ in comparison with the antioxidant potency of standard amounts of Trolox, the water-soluble vitamin $\mathrm{E}$ analogue ${ }^{(73)}$.

Table 6 shows the total antioxidant expressed as Trolox Equivalent Antioxidant Capacity, (TEAC) of lavender and marjoram EOs using the ABTS assay. The TEAC values ranged from 0.33 to $0.91 \mathrm{mM}$ Trolox equivalent at 25$100 \mu \mathrm{g}$ of L. angustifolia and M. hortensis EOs. However, M. hortensis essential oil showed greater $(0.91 \mathrm{mM} / 100 \mu \mathrm{g}$ of oil $)$ Trolox equivalent antioxidant capacity (TEAC) than L. angustifolia $(0.83 \mathrm{mM} / 100 \mu \mathrm{g}$ of oil). The scavenging activity of the ABTS radical by lavender and marjoram EOs was found to be appreciable. An inhibitory effect of marjoram EO $\left(\mathrm{IC}_{50}=36.18 \pm 0.16 \mu \mathrm{gmL}^{-1}\right)$ and lavender $\mathrm{EO}\left(\mathrm{IC}_{50}=42.60 \pm 0.22 \mu \mathrm{gmL}^{-1}\right)$ on $\mathrm{ABTS}$ free radicals was detected. This implies that the EOs may be useful for treating free radical-related 
pathological damage (especially at a higher concentration). Studied lavender and marjoram EOs were less radical scavenging agents than TBHQ.

TABLE 6 . Antioxidant activity of lavender (Lavandula angustifolia) and marjoram (Majorana hortensis) EOs using the corresponding concentrations (25, 50, $100 \mu \mathrm{G} / \mathrm{Ml})$ measured by ABTS method.

\begin{tabular}{|c|c|c|c|c|c|c|c|}
\hline \multirow{2}{*}{$\begin{array}{l}\text { Lamiaceae } \\
\text { species }\end{array}$} & \multicolumn{2}{|c|}{$25 \mu \mathrm{g} / \mathrm{ml}$} & \multicolumn{2}{|c|}{$50 \mu \mathrm{g} / \mathrm{ml}$} & \multicolumn{2}{|c|}{$100 \mu \mathrm{g} / \mathrm{ml}$} & \multirow[t]{2}{*}{$\mathrm{IC}_{50}(\mu \mathrm{g} / \mathrm{ml})$} \\
\hline & $\%$ inh & TEAC & $\%$ inh & TEAC & $\%$ inh & TEAC* & \\
\hline $\begin{array}{l}\text { Lavender } \\
\text { (L. angustifolia) }\end{array}$ & $39.1 \pm 1.3$ & $0.33 \pm 0.01$ & $55.7 \pm 1.7$ & $0.52 \pm 0.02$ & $81.7 \pm 2.0$ & $0.83 \pm 0.02$ & $42.60 \pm 0.22$ \\
\hline $\begin{array}{l}\text { Marjoram } \\
(M . \text { hortensis })\end{array}$ & $41.4 \pm 2.1$ & $0.35 \pm 0.01$ & $61.4 \pm 2.4$ & $0.59 \pm 0.02$ & $88.6 \pm 1.9$ & $0.91 \pm 0.03$ & $36.18 \pm 0.16$ \\
\hline
\end{tabular}

* TEAC: Trolox equivalent antioxidant capacity (mM).

Moderate antioxidant activity in lavender and marjoram EOs can be ascribed to the considerable content of linalool, linalyl acetate, $\alpha$-muurolene, alloaromadendrene, $\beta$-phellandrene and $\beta$-pinene in the EO of lavender, in addition to terpinen-4-ol, $\alpha$-terpinol, $\gamma$-terpinene, spathulenol, linalyl acetate, sabinene hydrate, piperitol, $\beta$-caryophyllene and $\alpha$-pinene in the EO of marjoram. Similarly, high antioxidant activity has been attributed to the presence of $\alpha$ pinene in juniper berry (Citharexylum caudatum L.), germacrene in ylang-ylang (Cananga adorata), 4-terpineol in Mentha spicata ${ }^{(74)}$ and phenolic content in rosemary (Rosmarinus officinalis L.) extracts ${ }^{(75)}$. Synergistic interactions among herbal EO components that had high antioxidant activity may have also had a role to play. Ruberto and Baratta ${ }^{(76)}$ tested about 100 pure constituents of EOs and confirmed that the monoterpene hydrocarbons $\delta$-terpinene, $\alpha$-terpinene and $p$-cymene showed very high antioxidant activity. In our study $\gamma$-terpinene was a major component of the $M$. hortensis $\mathrm{CH}$ fraction.

Antioxidants may act in various ways such as scavenging the radicals, decomposing the peroxides and chelating the metal ions ${ }^{(77)}$. All these activities may be related to the diverse compounds present in EOs, including phenolic, terpens and sesquiterpens. The action mechanism set in motion by the antioxidant activity of these compounds is still not clearly understood. Miguel ${ }^{(78)}$ reported that these compounds are known for their properties to scavenge free radicals and to inhibit lipid oxidation by acting as chain-breaking peroxyl-radical scavengers. In addition, phenols directly scavenge reactive oxygen species. For Amensour et al. ${ }^{(79)}$, the antioxidant activity of essential oil is believed to be mainly due to their redox properties, which play an important role in adsorbing and neutralizing free radicals, quenching singlet and triplet oxygen, or decomposing peroxides. Thus, difference in composition of the EOs, specificity and sensitivity of each method might result in different antioxidant activity of the lavender and marjoram EOs by DPPH, B-Carotene and ABTS assays and may be useful for treating free radical- related pathological damage. 
Antibacterial activity

Table 7 summarizes the quantitative results (Minimal Inhibitory Concentrations, MIC) of the antibacterial effect of the essential oil from dry aerial parts of lavender and marjoram on the 6 reference strains assayed; two Gram negative bacteria "Escherichiea coli and Salmonella", three Gram positive bacteria "Bacillus cereus, Bacillus subtilis and Staphylococcus aureus" and yeast "Saccharomyces cerevisiae.

TABLE 7 . Antibacterial activity of lavender (Lavandula angustifolia) and marjoram (Majorana hortensis) essential oils on gram negative bacteria "escherichiea coli and salmonella"; gram positive bacteria "Bacillus cereus, B. subtilis and Staphylococcus aureus" and yeast "Saccharomyces cerevisiae".

\begin{tabular}{|l|c|c|}
\hline \multirow{2}{*}{ Test microorganisms } & \multicolumn{2}{|c|}{ MIC* } \\
\cline { 2 - 3 } $\begin{array}{l}\text { Gram negative bacteria } \\
\text { Escherichiea coli }\end{array}$ & $40 \mu \mathrm{l} / \mathrm{ml}$ & Marjoram EO \\
\hline Salmonella & $50 \mu \mathrm{l} / \mathrm{ml}$ & $25 \mu \mathrm{l} / \mathrm{ml}$ \\
\hline $\begin{array}{l}\text { Gram positive bacteria } \\
\text { Bacillus cereus }\end{array}$ & $10 \mu \mathrm{l} / \mathrm{ml}$ & $40 \mu \mathrm{l} / \mathrm{ml}$ \\
\hline Bacillus subtilis & $40 \mu \mathrm{l} / \mathrm{ml}$ & $5 \mu \mathrm{l} / \mathrm{ml}$ \\
\hline Staphylococcus aureus & $40 \mu \mathrm{l} / \mathrm{ml}$ & $15 \mu \mathrm{l} / \mathrm{ml}$ \\
\hline $\begin{array}{l}\text { Yeast : } \\
\text { Saccharomyces cerevisiae }\end{array}$ & $40 \mu \mathrm{l} / \mathrm{ml}$ & $20 \mu \mathrm{l} / \mathrm{ml}$ \\
\hline
\end{tabular}

Minimum Inhibition Concentration as \% (v/v)

From the recorded minimum inhibition concentration (MIC) of the EOs, we observed that, the oil was active against all bacterial strains. However this activity varies between the test bacteria and MIC of the EOs ranged from 5 to 50 $\mu \mathrm{l} / \mathrm{mL}(\mathrm{v} / \mathrm{v})$. Interestingly, E. coli which is a cause of serious food poisoning and occasionally death was inhibited by marjoram and lavender oil at $25,40 \mu 1 / \mathrm{ml}$, respectively. Similarly, the EO obtained from the aerial parts of L. angustifolia mill displays good antibacterial activity against four rhinitis-related bacteria including E. coli, Staphylococcus aureus, Micrococcus ascoformans and Proteus vulgaris. The ability of essential oil to disrupt the permeability barrier of cell membrane structures and the accompanying loss of chemiosmotic control are the mostly likely reasons for its lethal action ${ }^{(32)}$. In other studies, the bacteria demonstrating the biggest inhibition zones by diffusion method are not always the ones that present the lowest MIC and MBC (minimum bactericidal concentrations) values due to the fact that oil solubility and volatility affect the diameter of the growth inhibition zone ${ }^{(19)}$. In our study, the recorded MICs showed that the Gram +ve strains of bacteria are more sensitive to marjoram and lavender oils than Gram -ve strains with the MICs $(5-40 \mu 1 / \mathrm{ml})$. Marjoram EO exhibited the maximum activity against Bacillus cereus followed by $B$. subtilis. 
Indeed, the majority of the essential oils assayed for their antibacterial properties showed a more pronounced effect against the Gram +ve bacteria ${ }^{(80)}$. The resistance of Gram -ve bacteria to essential oils has been ascribed to their hydrophilic outer membrane which can block the penetration of hydrophobic compounds into target cell membrane ${ }^{(81)}$.

In our study, the great antibacterial activity correlates with the high content of linalool $(37.65 \%)$, B-pinene $(2.52 \%)$, low content of camphor and borneol in lavender oil and other components such as terpinen-4-ol, $\alpha$-terpinol, $\gamma$-terpinene (48.98, 11.75 and $9.64 \%$, respectively) in marjoram oil. Several studies demonstrated that, the antibacterial activity of many essential oils and spices could be ascribed to the presence of phenolic components or substances other than phenolic compounds ${ }^{(82)}$, presence of linalool and B-pinene ${ }^{(83,48)}$, oxygenated monoterpenes such as camphor, borneol, linalool and $\alpha$-terpineol ${ }^{(85-87)}$. Moreover, the compounds present in the greatest proportions are not necessarily responsible for the total activity; the involvement of less abundant constituents should also be considered $^{(88)}$, the presence of synergy between the major components and other constituents of the oils leading to various degrees of antimicrobial activity. It has been reported that the strains of $E$ coli that are not susceptible to the mixture of linalool-1,8-cineole are likely to be affected by linalool alone ${ }^{(89)}$, which suggests that possible antagonistic and synergistic effects may occur according to the tested micro-organism ${ }^{(19)}$.

Consequently, the antimicrobial activity of the investigated lavender and marjoram oils could be attributed to the high percentage of oxygenated monoterpenes and $\gamma$-terpinene the precursor of thymol (thymol inactivate bacterial strains in food system ${ }^{(90)}$, synergistic effect of some compounds in the oils as well as oxygenated sesquiterpenes ( $\alpha$-santalol, caryophyllene oxide, spathulenol, $\alpha$-bisabolol and nerolidol) should also be taken in consideration.

\section{Conclusions}

Egyptian lavender and marjoram herbs can be considered as good sources of natural compounds rich in nutrients, safer (due to absence of mycotoxin and fungal contaminants in both herbs) and may be effective substitutes for synthetically produced antioxidant and antimicrobial agents. Lavender and marjoram EOs could be safely used as a preservative material to control foodborne pathogens and spoilage bacteria, as a potential resource of natural antioxidants for food, cosmetic and pharmaceutical industries since their possible use as natural additives emerged from the tendency to replace synthetic preservatives with natural ones. Generally, marjoram was more effective than lavender in all studied trials. However, application of oils as a substitute for chemical fungicides, plant-origin products as antioxidant and antimicrobials needs to be addressed by regulatory authorities for most parts of these compounds 


\section{References}

1. Suhaj, M., Spice antioxidants isolation and their antiradical activity: A review. $J$. Food Comp. Anal. 19, 531-537 (2006).

2. Stevenson, D.E. and Lowe, T., Plant-derived compounds as antioxidants for health Are they all really antioxidants? In: Hancock R.D. (Ed.) Antioxidant Properties of Crops I. Func. Plant Sci. Biotech. 3 (Special Issue 1), 1-12 (2009).

3. Aberoumand, A., Survey on some food plants as source of antioxidants. Innovative Romanian Food Biotech. 8, 22-25(2011).

4. Hussain, A.I., Anwar, F., Iqbal, T. and Bhatti, I.A., Antioxidants attributes of four Lamiaceae essential oils. Pak. J. Bot. 43(2), 1315-1321(2011).

5. Williams, R.J., Spencer, J.P.E. and Rice-Evans, C., Flavonoids: Antioxidants or signalling molecules. Free Rad. Biol. Med., 36, 838-849 (2004).

6. Soobrattee, M.A., Neergheen, V.S., Luximon-Ramma, A., Aruoma, O.I. and Bahorun, T., Phenolic as potential antioxidant therapeutic agents: Mechanism and actions. Mutation Res. 579, 200-213(2005).

7. Ebadi, M.S., Herbal drug and their high demand in treating diseases. In: Phaemacodynamic Basis of Herbal Medicine, Ebadi, M.S. (Ed.). CRC Press, London, pp: 125-126(2006).

8. Valko, M., Leibfritz, D., Moncola, J.,Cronin, M.T.D., Mazura, M. and Telser, J., Free radicals and antioxidants in normal physiological functions and human disease. Int. J. Biochem. Cell Biol. 39, 44-84(2007).

9. Huda-Faujan, N., Noriham, A., Norrakiah, A.S. and Babji, A.S., Antioxidant activity of plants methanolic extracts containing phenolic compounds. Afr. J. Biotech. 8, 484-489(2009).

10. Nanasombat, S. and Teckchuen, N., Antimicrobial, antioxidant and anticancer activities of Thai local vegetables. J Med. Plants Res. 3(5), 443-449(2009).

11. Kulisic T., Radonic, A., Katalinic, V. and Milos, M., Use of different methods for testing antioxidative activity of oregano essential oil. Food Chem. 85, 633-640(2004).

12. Hossain, M.B., Brunton, N.P., Barry-Ryan, C., Martin-Diana, A.B. and Wilkinson, M., Antioxidant activity of spice extracts and phenolics in comparison to synthetic antioxidants. Rasayan J. Chem. 1, 751-756(2008).

13. Yang, S.A., Jeon, S.K., Lee, E.J., Shim, C.H. and Lee, S.I., Comparative study of the chemical composition and antioxidant activity of six essential oils and their components. Nat. Prod. Res. 24,140-151(2010).

14. Delamare, A.P.L., Moschen-Pistorello, I.T., Artico, L., Atti-Serafini, L. and Echeverrigaray, S. , Antibacterial activity of the essential oils of Salvia officinalis L. and Salvia triloba L. cultivated in South Brazil.. Food Chem. 100, 603-608(2007). 
15. Oussalah, M., Caillet, S., Saucier, L. and Lacroix, M. , Inhibitory effects of selected plant essential oils on the growth of four pathogenic bacteria: E. coli O157:H7, Salmonella Typhimurium, Staphylococcus aureus and Listeria monocytogenes. Food Contr. 18, 414-420(2007).

16. Thanaboripat, D., Suvathi, Y., Srilohasin, P., Sripakdee, S., Patthanawanitchai, O. and Charoensettasilp, S., Inhibitory effect of essential oils on the growth of aspergillus flavu. Kmitl Sci. Tech. J. 7 (1), 1-7(2007).

17. Chun, S.S., Vattem, D.A., Lin, Y.T. and Shetty, K., Phenolic antioxidants from clonal oregano (Origanum vulgare) with antimicrobial activity against Helicobacter pylori. Process Biochem. 40, 809-816(2005).

18. Goodner, K.L., Mahattanataweea, K., Plotto, A., Sotomayor, J.A. and Jordan, M.J., Aromatic profiles of Thymus hyemalis and Spanish T. vulgaris essential oils by GC-MS/GC-O. Ind. Crop Prod. 24(3), 264-268(2006).

19. Bouhdid, S., Skali, S.N., Idaomar, M., Zhiri, A., Baudoux, D., Amensour, M. and Abrini, J., Antibacterial and antioxidant activities of Origanum compactum essential oil. Afr. J. Biotech. 7 (10), 1563-1570(2008).

20. Piccaglia, R., Marotti, M., Giovanelli, E., Deans, S.G. and Eaglesham, E., Antibacterial and antioxidant properties of Mediterranean aromatic plants. Ind. Crop Prod. 2, 47-50(1993).

21. Pedro, A.S., Cabral-Albuquerque, E., Ferreira, D. and Sarmento, B., Chitosan An option for development of essential oil delivery systems for oral cavity care. Carbohydrate Polymers, 76, 501-508(2009).

22. Katona, J.M., Sovilj, V.J. and Petrovi, L.B., Microencapsulation of oil by polymer mixture-ionic surfactant interaction induced coacervation. Carbohydrate Polymers, 79, 563-570(2010)

23. Ietswaart, J. H., A Taxonomic Revision of the Genus Origanum (Labiatae), Leiden University Press, Leiden (1980).

24. Yang, Y.C., Lee, H.S., Clark, J.M. and Ahn, Y.J., Insecticidal activity of plant essential oils against Pediculus humanus capitis (Anoplura: Pediculidae). J. Med. Entomol. 41(4), 699-704(2004).

25. Al-Harbi, N. O., Effect of marjoram extract treatment on the cytological and biochemical changes induced by cyclophosphamide in mice. J. Med Plants Res. 5(23), 5479-5485(2011).

26. El-Ghorab, A.H., Mansour, A.F. and El-Massry, K.F., Effect of extraction methods on the chemical composition and antioxidant activity of Egyptian marjoram (Majorana hortensis Moench). Flav. Fragr. J. 19, 54-61(2004).

27. Cristiani, M.D, Arrigo, M., Mandalari, G., Castelli, F., Sarpietro, M.G. and Micieli, D., Interaction of four monoterpenes contained in essential oils with model membranes: Implications for their antibacterial activity. J. Agric. Food Chem. 55, 6300-6308(2007).

Egypt. J. Chem. 56, No.1(2013) 
28. Barbosa, L.N.,Rall, V.L.,Fernandes, A.A., Ushimaru, P.I., Da S.P.I., Fernandes, A. Jr., Essential oils against foodborne pathogens and spoilage bacteria in minced meat. Foodborne Pathog. Dis. 6 (6),725-728(2009).

29. Prashar, A., Locke, I.C. and Evans, C.S., Cytotoxicity of lavender oil and its major components to human skin cells. Cell Proliferation 37 (3), 221-229(2004).

30. Hassiotis, C.N., Tarantilis, P.A., Daferera, D. and Polissiou, M.G., Etherio, a new variety of Lavandula angustifolia with improved essential oil production and composition from natural selected genotypes growing in Greece. Industrial Crops and Products, 32, 77-82(2010).

31. Viuda-Martos, M., Mohamady, M.A., Fernández-López, J., Abd EIRazik, K.A., Omer, E.A., Pérez-Alvarez, J.A. and Sendra, E., In vitro antioxidant and antibacterial activities of essentials oils obtained from Egyptian aromatic plants. Food Cont. 22,1715-1722(2011).

32. Hui, L., He, L., Huan, L., Xiao Lan, L. and Guo, Z.A., Chemical composition of lavender essential oil and its antioxidant activity and inhibition against rhinitisrelated bacterial. Afr. J. Microbiol Res. 4 (4), 309-313(2010).

33. Verma, R.,Verma, R., Chauhan, A. and Yadav, A., Changes in the essential oil composition of Majorana hortensis Moench. cultivated in India during plant ontogeny. J. Serb. Chem. Soc. 75, 441-447(2010b).

34. Peterson, S.W.,Ito, Y.,Horn, B.W. and Goto, T., Aspergillus bombycis, a new aflatoxigenic species and genetic variation in its sibling species. A. nomius, Mycologia, 93(4), 689-703(2001).

35. Rodriguez-Amaya, D.B. and Sabino, M., Mycotoxin research in Brazil: The last decade in review. Braz J. Microbiol. 33, 1-11(2002).

36. Wang, J.S. and Groopman, J.D., DNA damage by mycotoxins. Mutat.Res. 424, 167 181(1990).

37. Orsi, R.B., Olivelra, C.A., Dillan, P., Xavier, J.G., Direito, G.M. and Cornea, B., Effects of oral administration of aflatoxinB1 and fumonisin B1 in rabbits. Chem Biol. Interact. 170, 201-208(2007).

38. Alwakeel, S.S., The effect of mycotoxins found in some herbal plants on biochemical parameters in blood of female Albino Mice. Pak. J. Biol. Sci. 12 (8), 637-642(2009).

39. El-Shafie, A.E., Al-Rash, T.A., Al-Bahq, S.N. and Bakheit, C.S., Fungi and aflatoxim associated with spices in the Sultanate of Oman. Mycopathologia, 155,155160 (2002).

40. El-Kady, I.A., El-Maraghy, S.S.M. and Mostafa, E.M., Natural occurrence of mycotoxins in different spices in Egypt. Folia Microbiol (Praha), 40(3), 297300(1995). 
41. A.O.A.C., Association of Official Agriculture Chemists. Official Methods of Analysis. $16^{\text {th }}$ ed., Washington D.C. USA (1995).

42. A.O.A.C. Association of Official Agriculture Chemists. Official Methods of Analysis. $17^{\text {th }}$ ed., Washington D.C. USA. Chapter 4. 969.3 and 991.39 fatty acids in oils and fats preparation of Methyl Esters Boron Tri- Flouride- AOAC-IUPAC method codexadopted- AOAC Method. Chapter 41, pp. 19-20(2000).

43. A.O.A.C. , Official Methods of Analysis. $17^{\text {th }}$ ed., Washington D.C. USA., Vol. 1, P. 40-41(2002).

44. Iva J., Patrick, B. and Lse, S., Determination of trace elements in pumpkin seed oils and pumpkin seeds by ICP-AES. J. Anal. At. Spectrum, 18, 54-58(2003).

45. A.O.A.C., (Official Method 968.22). "Aflatoxin in Peanuts and Peanut Product" CB Method. Washington, D.C. AOAC (1988).

46. AOAC, Official Method of Analysis ., $18^{\text {th }}$ ed., Washington D.C. USA. Volume (2) Chapter (49):- No. 991.31p21-23 for Aflatoxins and No. 2000.03 p.65-66 for Ochratoxins. AOAC- IUPAC Method Codex- Adopted- AOAC Method (2006).

47. AOAC, Official Method of Analysis. $18^{\text {th }}$ ed., Washington D.C. USA. Chapter 3. 1.03 and 3. 1.05 AOAC- IUPAC Method Codex- Adopted- AOAC Method (2005).

48. Adams, R.P., Identification of essential oil components by gas chromatography/ quadrupole mass spectroscopy. Allured Publishing Corp., Carol Stream (2001).

49. Matthus, B., Antioxidant activity of extracts obtained from residues of different oilseeds. J. Agric. Food. Chem., 50, 3444-3452(2002).

50. Yen, G.C. and Duh, P.D., Scavenging effect methanolic extracts of peanut hulls on free-radical and active oxygen species. J. Agric. Food Chem. 42, 629-632(1994).

51. Wettasinghe, M. and Shahidi, F. , Antioxidant activity of preformed cooked curedmeat pigment in a b-carotene/linoleate model system. Food Chem. 58, 203-207(1997).

52. Cai, Y., Luo, Q, Sun, M. and Corke, H., Antioxidant activity and phenolic compounds of 112 traditional Chinese medicinal plants associated with anticancer. Life Sci. 74, 2157-2184(2004).

53. Jones, R.N., Barry, A.L., Gavan, T.L. and Washington, J.A. , In E.L., Lennette (Ed.), Manual of Clinical Microbiology, American Society for Microbiology, Washington, 972(1985).

54. Mahindru, S. N., Manual of Indian Spices, Academic Foundation, New Delhi (1994).

55. Verma, R.S., Sashidhara, K.V., Yadav, A. and Naqvi, A.A., Essential oil composition of Majorana hortensis (Moench) from subtropical India. Acta Pharm. Sci. 52, 19-22(2010a).

Egypt. J. Chem. 56, No.1(2013) 
56. Marotti, M., Dellacecca, V., Piccaglia, R. and Giovanelli, E., Effect of harvesting stage on the yield and essential oil composition of peppermint (Mentha x piperita L.). Acta. Hortic. (ISHS) 344, 370-379(1993).

57. Vera, R.R. and Chane-Ming, J., Chemical composition of the essential oil of marjoram (Origanum majorana L.) from Reunion Island. Food Chem. 66,143145(1999).

58. Rao, L.J.M., Quality of essential oils and processed materials of selected spices and herbs. J. Med. Arom. Pl. Sci. 22, 808-816(2000).

59. Novak, J., Langbehn, J., Pank, F. and Franz, C.M., Essential oil compounds in a historical sample of marjoram (Origanum majorana L., Lamiaceae). Flav. Fragr. J. 17, 175-180(2002).

60. Mishra, A.C., Negi, K.S., Suneja, P. and Maheshwari, M.L., Performance of marjoram (Majorana hortensis Moench.) in Uttranchal Pradesh. Ind. Perf. 48 (1), $41-$ 45(2004).

61. Barazandeh, M.M., Essential oil composition of Origanum majorana L. from Iran. $J$. Essent. Oil Res. 13, 76-77(2001).

62. Schlesier, K., Harwat, M., Bohm, V. and Bitsch, R., Assessment of antioxidant activity by using different in vitro methods. Free Radical Research, 36, 177187(2002).

63. Huang, D.J., Ou, B.X. and Prior, R.L., The chemistry behind antioxidant capacity assays. J. Agric. Food Chem. 53(6), 1841-1856(2005).

64. Blois, M.S., Antioxidant determinations by the use of stable free radical. Nature, 26, 1199-1200(1958).

65. Koleva, I.I.,Van Beek, T.A., Linssen, J.P.H., de Groot, A. and Evstatieva, L.N., Screening of plant extracts for antioxidant activity: A comparative study on three testing methods. Phytochem. Anal. 13, 8-17(2002).

66. Pellegrini, R.R., Proteggente, A., Pannala, A., Yang, M. and Rice-Evans, C., Antioxidant activity applying an improved ABTS radical cation decolorizing assay. Free Radic. Biol.Med. 26 (9-10), 1231-1237(1999).

67. Brand-Williams,W., Cuvelier, M.E. and Berset, C., Use of free radical method to evaluate antioxidant activity. Lebensmittel Wissenschaft und Technologie, 28, 2530(1995).

68. Baumann J., Wurn, G. and Bruchlausen, F.V., Prostaglandin synthetase inhibiting $\mathrm{O}_{2}$ radical scavenging properties of some flavonoids and related phenolic compounds. Naunyn-Schmiedeberg's Arch. Pharmacol. 308, R27(1979).

69. Lim, Y.Y., Lim, T.T. and Tee, J.J., Antioxidant properties of guava fruit: comparison with some local fruits. Sunway Academic Journal, 3, 9-20(2006). 
70. Conforti, F. Marrelli, M., Mnichini, F., Tundis, R., Statti, G.A., Solimene, U. and Menichini, F., Chemical composition and protective effect of oregano (Origanum heracleoticum L.) ethanolic extract on oxidative damage and on inhibition of NO in LPS-stimulated RAW 264.7 macrophages. J. Enz. Inh. Med. Chem. 26, 404-41(2011).

71. Khasawneh, M.A., Elwy, H.M., Fawzi, N.M., Hamza, A.A., Chevidenkandy, A.R. and Hassan, A.H., Antioxidant activity, lipoxygenase inhibitory effect and polyphenolic compounds from Calotropis procera (Ait.) R. Br. Res. J. Phytochem. 5, 80-88(2011).

72. Fukumoto, L.R. and Mazza, G., Assessing antioxidant and prooxidant activities of phenolic compounds. J. Agric. Food Chem. 48, 3597-3604 (2000).

73. Miller, N.J. and Riceevans, C.A., Spectrophotometric determination of antioxidant activity [review]. Redox Report , 2 (3), 161-171(1996).

74. Wei, A. and Shibamoto, T., Antioxidant activities and volatile constituents of various essential oils. J. Agric. Food Chem. 55, 1737-1742(2007).

75. Moreno, S., Scheyer, T., Romano, C.S. and Vojnov, A.A., Antioxidant and antimicrobial activities of rosemary extracts linked to their polyphenol composition. Free Radical Res. 40, 223-231(2006).

76. Ruberto, G. and Baratta, M.T., Antioxidant activity of selected essential oil components in two lipid model systems. Food Chem. 69, 167-174(2000).

77. Çam, M., His, il, Y. and Durmaz, G., Classification of eight pomegranate juices based on antioxidant capacity measured by four methods. Food Chem. 112(3), 721726(2009).

78. Miguel, M.G., Antioxidant activity of medicinal and aromatic plants. A review. Flav. Frag. J. 25, 291-312(2010).

79. Amensour, M., Sendra, E., Jamal, A., Bouhdid, S., Pérez-Alvarez, J.A. and Fernández- López, J., Total phenolic content and antioxidant activity of myrtle (Myrtus communis) extracts. Nat. Prod. Comm. 4(6), 819-824(2009).

80. Wan, J., Wilcock, A. and Coventry, M.J., The effect of essential oils of basil on the growth of Aeromonas hydrophila and Pseudomonas fluorescens. Appl. Microbiol. 84,152-158(1998).

81. Inouye, S., Yamaguchi, H. and Takizawa, T., Screening of the antibacterial effects of variety of essential oils on respiratory tract pathogens, using a modified dilution assay method. J. Infect. Chemother, 7, 251-254(2001).

82. Nimsha, S., Caffina, W.N.,Turnera, M.S. and Dykesb, G.A., In vitro antimicrobial activity of less-utilized spice and herb extracts against selected food-borne bacteria Food Control, 21 (10), 1408-1414(2010).

83. Bagamboula, C.F., Uyttendaele, M. and Debevere J., Inhibitory effect of thyme and basil essential oils, carvacrol, thymol, estragol, linalool and p-cymene towards Shigella sonnei and S. flexneri. Food Microbiol. 21, 33-42(2004).

Egypt. J. Chem. 56, No.1(2013) 
84. Sonbolia, A., Babakhanib, B. and Mehrabian, A.R., Antimicrobial activity of six constituents of essential oil from Salvia. Z. Naturforsch. 61c, 160-164(2006).

85. Carson, C.F. and Riley, T.V., Antimicrobial activity of the major components of the essential oil of Melaleuca alternifolia. J. Appl. Bacteriol. 78, 264-269(1995).

86. Al-Massarany, S.M., Abbas, F.A., Demirci, B.,Baser, K.H.C., Khan, S.I., AlRehaily, A.J.J., Mossa, S. and Abourashed, E.A.,Chemical composition and biological evaluation of the essential oil of Commiphora opobalsamum L. J. Herbs spices Med. Plants, 13, 111-121(2007).

87. Mothana, R.A., Al-Rehaily, A.J. and Schultze, W., Chemical analysis and biological activity of the essential oils of two endemic Soqotri Commiphora Species. Molecules, 15, 689-698(2010).

88. Cimanga, K., Kambu, K.,Tona L., Apers, S., De Bruyne, T., Hermans, N., Totté J., Pieters, L. and Vlietinck, A.J., Correlation between chemical composition and antibacterial activity of essential oils of some aromatic medicinal plants growing in the Democratic Republic of Congo. J. Ethnopharmacol. 79, 213-220(2002).

89. Faleiro, M.L., Miguel, M.G.,Ladeiro, F., Venâncio, F., Tavares, R., Brito, J.C., Figueiredo, A.C., Barroso, J.G. and Pedro, L.G., Antimicrobial activity of essential oils isolated from Portuguese endemic species of Thymus. Lett. Appl. Microbiol. 36, 35-40(2003).

90. Valero, M. and Frances, E., Synergistic bactericidal effect of carvacrol, cinnamaldehyde or thymol and refrigeration to inhibit Bacillus cereus in carrot broth Food Microbiol. 23, 68-73(2006). 


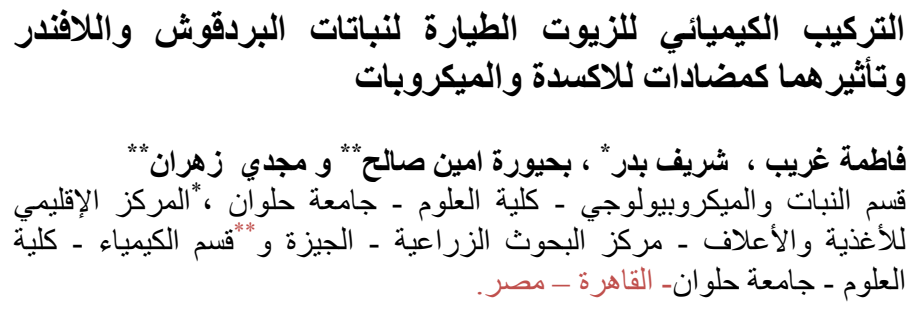

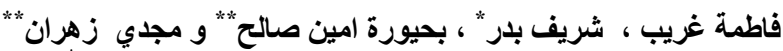

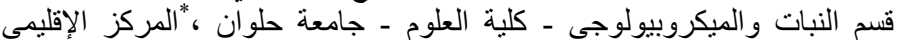

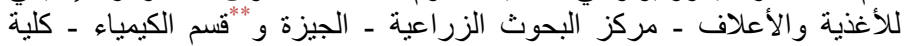

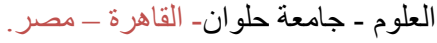

تم دراسة التركيب الكيميائي للزيوت الطيارة لنباتي البردقوش و اللافندر وتأثير هما

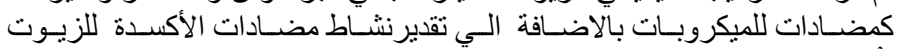

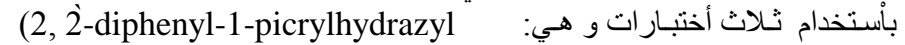
(B-carotene و طريقة (DPPH) radical scavenging assay) (2,2'-azinobis (3-ethylbenzothiazoline- و طريقة bleaching test) 6-sulfonic acid (ABTS))

- مجل زيت البردقوش أعلي نشاط مضادات للأكسدة بالطرق الثلاثة المستخدمة

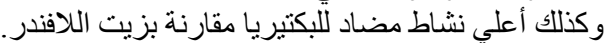

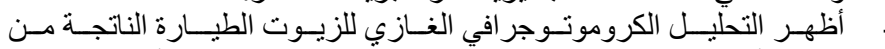

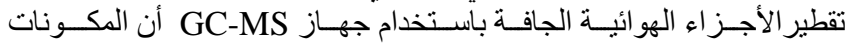

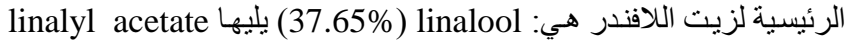
allo-aromadendrene $و$ و (8.59 \%) $\alpha$-muurolene 9 (15.29\%)

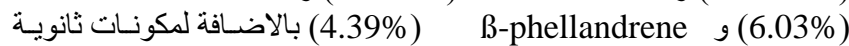
أخرى. و أن المكونات الرئيسية لزيت البردقوش هي: terpinen-4-ol (48.98\%) و $\quad \gamma$-terpinene $9.64 \%$ و sabinene, $2.58 \%)$ linalyl acetate $9(3.51 \%)$ spathulenol . $2.30 \%)$ hydrate

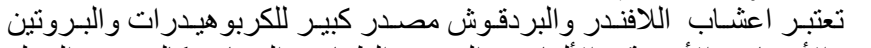

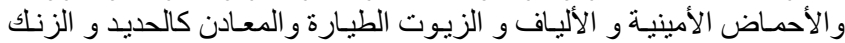

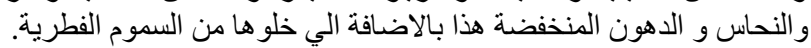

